\title{
Roadmap of Tibetan Independence
}

\section{Wang Lixiong}

\section{(2) OpenEdition}

Journals

Édition électronique

URL : http://journals.openedition.org/chinaperspectives/4850

DOI : $10.4000 /$ chinaperspectives.4850

ISSN : 1996-4617

\section{Éditeur}

Centre d'étude français sur la Chine contemporaine

\section{Édition imprimée}

Date de publication : 1 septembre 2009

ISSN : 2070-3449

\section{Référence électronique}

Wang Lixiong, « Roadmap of Tibetan Independence », China Perspectives [En ligne], 2009/3 | 2009, mis en ligne le 01 septembre 2012, consulté le 28 octobre 2019. URL : http://journals.openedition.org/ chinaperspectives/4850; DOI : 10.4000/chinaperspectives.4850

(C) All rights reserved 


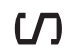

\title{
Roadmap of Tibetan
}

\section{Independence}

\author{
WANG LIXIONG
}

Wang Lixiong published his "Roadmap of Tibetan Independence" on the Internet in November 2008, after a relative easing of tensions following the spring uprising and just after the conclusion of the Beijing Olympic Games. ${ }^{(1)}$ It offers his interpretation of the Tibet issue with a novel analytical approach that he formulated after the Tibetan protests. His original view of the Tibet crisis takes into account its deeper causes and charts a path towards Tibetan independence. "Roadmap" consists of three parts: 1) The March Incident in Tibet is a Watershed, 2) The difficulties of an imperial system of government, and 3) The Road to Tibetan Independence. The first part has been translated into English by Kong Lingxi and disseminated widely on the Internet. ${ }^{(2)}$ It therefore seemed important to publish the second part, which is more relevant to understanding the author's views as it contains a detailed analysis of the nature of bureaucratic institutions and details the system's failings. In order to give a general idea of what Wang's text has to say, a summary of the first part precedes the translation. The third part, not translated here, presents Wang's vision of different scenarios for achieving independence, which he believes can only come about through massive violence and bloodshed. TibetInfoNet reported on 13 June 2009 that Wang was in Dharamsala for a twomonth visit organised by the Association of Tibetan writers. ${ }^{(3)}$ (Lara Maconi, translated by N. Jayaram)

\section{The March Incident in Tibet is} a Watershed (a summary)

W ang Lixiong contends that after the March 2008 incidents, the possibility of Tibetan independence has come under serious consideration by people such as himself and a section of international observers. Wang's thesis is that Tibetan independence has become an emerging issue thanks to the "anti-secession" organs in China's bureaucracy. In fact, Wang says, it is in the interests of these institutions and their personnel to stoke and exaggerate fears of separatist problems in China, thereby conferring on themselves greater decision-making power in the state machinery, matched by means of action and intervention. During times of heightened tension, the bureaucrats in charge of "anti-secession" work command a decision-making power even greater than that of the central government and its leaders. The harsh measures adopted by these bureaucrats to deal with a given crisis lead to a general hardening of positions, provoking the introduction of even harsher measures, which in turn produce more violent reactions. According to Wang, the bureaucrats vested with "antisecession" responsibilities knowingly let this process continue in order to keep crises smouldering. In this way they are able to consolidate their perceived indispensability to the state machinery, their decision-making power and influence, and their economic interests as well. The new characteristic of the bureaucrats' action during the 2008 uprising, Wang says, was the ethnic and racial twist they gave the Tibet issue, inciting a large section of Han Chinese around the world to spew hatred towards Tibetans and line up behind the government's policies. (Lara Maconi, translated by N. Jayaram)

\section{The difficulties of an imperial system of government}

\section{"Anti-separatism" as a profession}

The most important function of an imperial state is to keep the empire's territory intact. As a result, the anti-separatism institutions established for this purpose hold a privileged position in the State. Phuntsog Wanggyal, founder of the

1. Xizang duli luxiantu." The Chinese original can be found on Wang Lixiong's weblog, Wang Lixiong wenku, URL: http://wlx.sowiki.net//. The specific URL for the article is http://wlx.sowiki.net/?action=show\&id=321.

2. An English translation of the first part of "Roadmap of Tibetan Independence" by Kong Lingxi can be found at http://wlx.sowiki.net//?action=show\&id=322.

3. www.tibetinfonet.net, News Digest, 6 June 2009 - 19 June 2009. TibetInfoNet also reported the visit to Dharamsala of a group of Chinese writers invited by the Association of Tibetan writers, who met the Dalai Lama. 


\section{Chinese Intellectuals and the Tibet Issue}

$\mathrm{S}$ incere and wide-ranging interest in Tibet on the part of a segment of the Chinese population is much more recent than that of Westerners regarding the Roof of the World. Until the late 1980s, Chinese writings on Tibet were rare, apart from those published by the propaganda apparatus. But times have changed. Since Ma Yingjeou's election as President of Taiwan and the Kuomintang's return to power, the situation across the Taiwan Strait no longer seems to be an unsolvable issue standing in the way of national unity. Suddenly, the Tibet issue looms disproportionately large, obliging people engaged with Chinese politics as well as strategists of the democratic movement in exile to take a much clearer stand than before and to join, or disassociate from, the issue's rare pioneers from the 1970s.

One of the first Chinese dissidents to broach the Tibet issue was Wei Jingsheng. Even his initial writings during the Beijing Spring of 1978-1979 expounded on the fate of Tibetan political prisoners who had been placed in the Qincheng jail on Mao Zedong's order in the 1960s and 1970s. During his own 18-year-long-incarceration for thought crime, Wei addressed long missives to Deng Xiaoping setting out his vision of Sino-Tibetan relations and making suggestions on the attitude to take regarding Tibet. During his brief spell of freedom between September 1993 and March 1994, he managed to send a message by courier to the Dalai Lama in India, pledging unwavering friendship and expressing a long-held desire to meet him. This was realised in 1998, some months after Wei's expulsion to the United States. The two men have since exchanged ideas during many random international gatherings.

Another noted dissident, Liu Xiaobo, dared address an open letter in 1996 calling on then President and Party General Secretary Jiang Zemin to change his policy on Tibet and advocating a new alliance between the Communist Party and the Kuomintang. This audacity earned him three years of re-educa- tion through labour. In an article published just before his most recent arrest in December 2008, Liu said China would not be democratic so long as Tibet was denied freedom.

Adoption of such public stances has, however, remained extremely rare both within and outside China. After 1989 and the exit westwards of many intellectuals, meetings between leading figures such as Chen Yizi, Cai Chongguo, and Wan Runnan and the Dalai Lama took place more frequently than before. Convinced that China's democratisation was imminent, the political exiles addressed Tibetans as if they would solve the "Tibet problem" as soon as they ascended to power, but they often did so with a degree of condescension, not suspecting that the Tibetans could be planning to demand self-determination or worse, independence.

Some rare and original dissidents such as Tang Boqiao, who took refuge in France and then the United States, or Moli in Sweden, took up Tibet's cause and sought to champion the Tibetan viewpoint to their Chinese readers. They were soon disparaged or worse, ignored - such is the conviction among most Chinese people that Tibet belongs to China.

Within China, the most devoted defender of Tibetan culture is the writer Wang Lixiong, who first travelled to Tibet in 1984 and returned there between 1995 and 1998 to write a book entitled Tianzang (Sky Burial: The Fate of Tibet). After visiting India and holding long talks with the Tibetan spiritual leader, Wang published $Y$ u Dalailama Duihua (Discussions with the Dalai Lama) in 2002. The following year he signed a petition along with 24 other Chinese intellectuals demanding that independent lawyers be present during the trial of Tenzin Delek Rinpoche, who was accused of complicity

1. Gongmeng or Open Constitution Initiative, Zangqu 3.14 shijian shehui jingji chengyin diaocha (Research into the Social and Economic Causes of the March 14th Event in Tibet), http://www.gongmeng.cn/@admin/upload_files/down/BOZsHov8 915454.doc. 
in a bomb attack in December 2002. Wang holds that the "middle way" favoured by the Dalai Lama to resolve the Tibet issue is the only viable solution, and has urged Chinese authorities to see it as the basis of future negotiations. He has set out his viewpoint at length in an article translated in English under the title Unlocking Tibet.

Since the March 2008 uprising in Lhasa and the renewed repression that engulfed the Tibet $\mathrm{Au}$ tonomous Region and the Tibetan areas in the provinces of Sichuan, Qinghai, and Gansu, more and more Chinese citizens have become concerned over the situation in Tibet and have supported moves for a rapprochement between China and the Tibetans in exile in hopes of calming the extreme tensions growing both within and outside of China. Yang Jianli, a Fellow at Harvard University, seeks to promote intercultural and interfaith dialogue through an organisation he founded called Initiatives for China. In Washington, Wei Jingsheng, joined by Vietnamese, Burmese, Tibetan, and Uyghur activists, formed an alliance for democracy in Asia in 2007. In Paris, a Sino-Tibetan friendship alliance was formed on the occasion of the 20th anniversary of the Tiananmen massacre, with Chinese and Tibetans jointly commemorating the victims of the 1989 repression.

More significantly, many lawyers and intellectuals in China have openly tried to introduce concepts of rights and historical and sociological reflection into discussions aimed at calming tensions in the Tibetan regions. Right from the spring of 2008, members of a research organization named Beijing Gongmeng Consulting Co., Ltd., or Open Constitution Initiative, ${ }^{(1)}$ published a long study on the social and economic causes of the 14 March 2008 events in Tibetan areas. The authors - Fang Kun, Li Xiang, Huang $\mathrm{Li}$, and Wang Hongzhe - underline the loss of real autonomy in the border regions of China and link social violence to the economic situation in Tibet, Xinjiang, and Inner Mongolia, characterised by joblessness, poverty, and a lack of basic services and investment in the education of non-Han ethnic groups. They point to the Chinese government's commitments on regional autonomy spelled out in the Constitution.
Further, intellectuals from diverse backgrounds, including Wang Lixiong, Liu Xiaobo, writer Yu Jie, professor Ding Zilin, whose son died during the Tiananmen incident, and a few others joined to circulate a petition entitled "Twelve Suggestions for Dealing with the Tibetan Situation," which called for an end to censorship of reporting on repression in the Tibetan zones. In addition, 21 lawyers, including Teng Biao, Xu Zhiyong, Jiang Tianyong, and Li Fangping, offered their services to Tibetans brought before the Chinese courts. The zeal of this initiative contributed to an official crackdown in which some 20 lawyers lost their licence to practice on 1 June 2009, but Li Fangping nevertheless succeeded in obtaining the release of a monk, Phurbu Rinpoche, falsely accused of a terrorist act in April 2009. According to $\mathrm{Li}$, it was the first time a Chinese lawyer had acted on behalf of a Tibetan.

It is reassuring that more and more voices are being raised to ensure that the Tibet issue does not go the way of the "Chechen problem," with violence becoming the only tool for dealing with the a forced coexistence. $\bullet$

\section{- Translated by N. Jayaram}


Wang Lixiong and the Dalai Lama in Dharamsala, June 2009.

(c) Wang Lixiong

Tibetan Communist Party and formerly a high official in the Chinese Communist Party (CCP), described the bureaucrats that populate these institutions as utilising this perceived necessity of "anti-separatism" to make a living, establish their careers, and make their fortunes. This is because the greater the problem posed by separatism, the more power and resources these institutions and bureaucrats are awarded by the empire. At a fundamental level, this has created the instinctive hope among these bureaucrats that separatism will exist permanently as an issue. Given that at both the institutional and personal levels it is in their interest for the nationality issue to remain unresolved, they deliberately exacerbate existing conflicts and overstate the dangers of separatism. They cast incidents in the most serious light possible, exaggerate situations and make them appear much more acute than they really are, and create issues when there are none. In order to emphasise their political accomplishments, they sometimes take excessively hard-line approaches in dealing with these events, escalating conflicts to a higher level. When mistakes are made, they refuse to admit responsibility, shifting it instead onto others or using bigger mistakes to conceal smaller ones.

This flawed management style is sometimes attributed to the stupidity of executive officials. This is certainly inaccurate, as officials are not lacking in intelligence. They may be aware that their behaviour will harm society, but they continue to carry on in this way because their aim is not to resolve the underlying issues but to benefit personally from their management. Take, for example, the Chinese diplomats stationed in foreign countries, many of whom are educated in the West and spend much time living abroad. When they organise patriotic demonstrations of overseas Chinese residents and students, they know that these events will repulse the people and the media of their host country, thereby hurting China's image abroad. But their career in the bureaucracy doesn't depend on the host country's favour or disgust but rather on satisfying China's leaders and their institutions. Chinese leaders feel pride when they see images of their national flag and patriotic Chinese out in Western countries in full force, and the diplomats are then more likely to be promoted. This is their motivation. As far as damaging the country goes, this is not their responsibility and they will not be required to shoulder any blame, so they have nothing to worry about.

I discussed earlier how the bureaucratic clique concerned with Tibet have placed all blame on the Dalai clique, since this is the best way for them to avoid responsibility. But this doesn't apply to the Ministry of Public Security, the

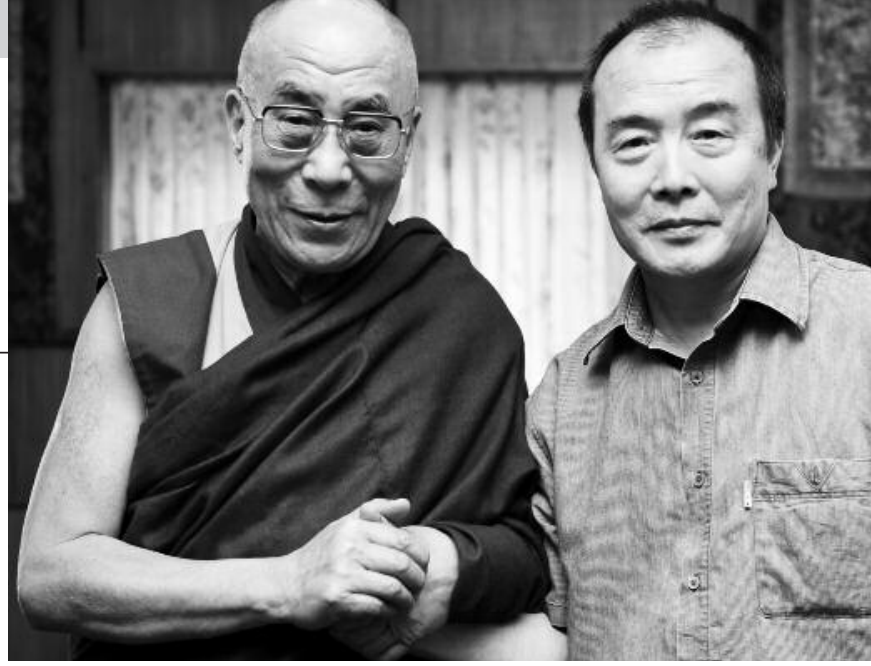

Ministry of State Security and the People's Armed Police. Their functions are to prevent sabotage by "hostile" or overseas forces, and because the March Incident - "organized, premeditated, and carefully planned by the Dalai Clique" was successful, these institutions should have to take full responsibility. Why do they allow a narrative of sabotage to circulate, one that casts them in a bad light? At the same time, this also shows the complexity of the bureaucracy: the most basic instinct of the individual official is to shift responsibility, but a more skilful approach is to turn crisis into opportunity. The agencies concerned with security did not therefore blame themselves, instead claiming that they were crippled by "external factors" such as lack of resources, insufficient budget, excessive restrictions on their power, and mild policies. When they violently shut down the Tibetan protests, they were immediately seen as heroes in the "struggle against the enemy." Not only were they free from blame, they were actively praised as well. At the same time, it demonstrates to the public once again that ruthless crackdowns are the only efficient method available. Having shut down the protests, they reflect on the previous approaches they took-lack of resources, excessive restrictions on power, mild policies-and draw lessons about their effectiveness. In this way, they are able to request more resources and power from higher authorities to implement their hard-line policies and raise their own status. Such tactics are certainly effective-for enhancing the careers of the bureaucrats. By taking advantage of their information monopoly to overstate the brutality of events and the dangers of separatism, they can easily frighten the highest authorities within the empire. The imperial rulers, in turn, are always willing to pay the necessary price to maintain the integrity of territory.

The events that occurred in Tibet in the spring of 2008 are likely to interrupt the process of liberalisation in the Chinese state. Reform efforts already underway that were meant to ease police measures may also now be aborted. This is particularly true in regions with large populations of ethnic minorities: milder policies implemented before are now being revoked, while oppressive powers that were beginning to be dissipated are now being consolidated once more. In the name of anti-separatism and counter-terrorism, China's minority regions will inevitably be governed under authoritarian police states. This is in large part a result of "anti-sep- 
aratism" becoming the professional pursuit of a bureaucratic clique. For despite the larger system in which they find themselves, bureaucrats will always pursue their own interests-which should surprise no one. The bureaucratic-authoritarian system enables clever bureaucrats to harm the nation and regime for their own professional enhancement, which is why it contains the seeds of its own collapse.

\section{The democratic character of bureaucratic cliques}

It may seem strange that, although decisions in authoritarian regimes are made from top-down, the high authorities turn a blind eye when their subordinates behave in damaging ways in pursuit of their personal or institutional interests. Why do they not intervene? Even if dictators were shielded by false information in other historical cases, I do not think this is the case here. Instead, the nature of China's power structure is such that the high authorities have no way to override the situations created by their subordinates, even if they know better. This is because, in an authoritarian-bureaucratic system, the decisions of leaders can only be implemented through bureaucracy. Because of this, although the highest authorities can exercise absolute authority with regard to external players, they lack this actual power internally. They are only able to dictate policy and exercise their authority when it doesn't harm the interests of these institutions. Otherwise the bureaucrats will band together and employ tactics such as delay, distortion, and non-responsiveness to strip their leaders of their power in the process of policy implementation. This process by which the authority of authoritarian powers is diminished is what I call the democratic character of bureaucratic cliques [...].

The memory of [the Cultural Revolution] is deeply engraved upon a bureaucracy that suffered enormously during that era. Henceforth, the sentiment has been that no dictators should be allowed to destroy the bureaucratic cliques. In the post-Mao era, CCP campaigns for Party-building and developing democracy within the $\mathrm{CCP}$ are indeed strengthening the democratic character of the bureaucracy and shielding it from the whims of the authorities. The essence of this delegation of power-the main component of China's reform-is power-sharing among the bureaucratic cliques. The CCP has to date established a comprehensive system of internal restrictions, while the bureaucratic cliques have achieved the capacity to guard against official purges and block any line struggle that might lead to internal Party division. Today, the highest authorities of the CCP are weaker than at any other time in history. The power transfer has also been effectively pre-programmed, and the fundamental cause behind all this is the democratic character of bureaucratic cliques.

This is an essential change. In the era of "ideology-aboveall," power struggles at the highest level were carried out in the form of line struggle. Bureaucrats could only choose representatives along different factional lines and then rise and fall with their chosen line in a passive way. But when the CCP transformed from being ideologically-driven to being merely a power bloc, the bureaucracy-which implements the power of the regime and benefited most from the shiftbecame its core. With the decline of ideology, power struggles within the Party seem ill-founded and lacking in legitimacy. As the democratic character of the bureaucracy grows, inner-Party struggles that harm group interests will be boycotted by a unified collective of bureaucrats. The CCP has thus become less divided and more pragmatic. The top leaders are no longer dictators that lord over the bureaucratic cliques but are instead their coordinators and spokespersons. At the same time, the leaders can only enhance their own power by winning the support of the bureaucracy and maximising their interests.

The bureaucrats understand the machinery of state and can operate it skilfully, more or less possessing the ability to constrain the power of the top leaders, control the appointment of officials, and decide on the direction of policies. As long as they retain these capacities, they are not only able to avoid purges or "cultural revolutions" within the Party, but can also fend off actions they find unfavourable and increase their advantage as much as possible. So to view the CCP's promotion of inner-party democracy as a step toward the democratisation of China in general is completely mistaken. "Inner-party democracy" is just another name for the centuries-old democratic character of bureaucratic cliques. It has nothing to do with popular democracy.

\section{The Tibet Issue at an impasse}

It should be clear through the examination of the democratic character of bureaucratic cliques and theirs central role in the CCP why China's current Tibet policy is not likely to improve. I mentioned at the beginning that Tibet is governed by 13 agencies at the provincial or ministerial level, along with 24 anti-separatism departments at similar levels. The tactics they employ-deceiving those above, bullying those below, responding to policies from above with countermeasures from below, delaying unfavourable actions indefinite- 
ly-have been so effective that if even one agency refuses to implement a certain policy, there is not much the leaders can do-especially when the 24 departments are in alliance.

Compared to Mao Zedong and Deng Xiaoping, the current CCP leaders enjoy much less authority. They not only lack expertise, a celebrated history of achievement, and charisma, but they are all also bureaucrats, having been part of the bureaucracy for years and knowing the rules of officialdom all too well. Having been promoted, rung by rung, to the top positions, how could they not know the power of bureaucratic institutions? Yet because of this, they are not leaders by nature, but top bureaucrats who are not inclined to look beyond. They seek simply to remain in power, never daring to step outside their designated jurisdictions, so we can hardly expect them to show the same level of resolve and inclination toward change as Mao and Deng. The top CCP leaders did not act in response to the March Incident until long after it had broken out. Everything was handled by the antiseparatism agencies. This is a unique feature of the event. Those 24 departments took control of all the necessary elements of power, including legislation, military force, and propaganda. They formed a complete, unbroken chain in decision-making, implementation, and coordination. Even without leadership from their leaders, they were able to coordinate and operate on their own.

The CCP has also fallen into a trap of its own making. Its metamorphosis from a revolutionary party into merely a power bloc has left it with sovereignty as its only remaining substantial ideology-a sovereignty preserved through nationalism and making up the core of the CCP's power. The state has spared no effort in indoctrinating the people and continuously rewriting history, so that most Chinese now believe that China's imperial territory has belonged to China since ancient times. Given this narrative, bureaucrats simply occupy a politically-correct position and therefore easily win public support. Yet it also means that they would find it difficult to alter their position or public opinion. Anti-separatism can be seen as both a shield and a weapon: it protects bureaucrats, because none would dare express dissent with it, but they can also use it to launch an attack against others at any time. The alliance of the 24 anti-separatist institutions is extremely powerful-in addition to manifesting the only substantial ideology of the Party. Mobilizing their "innerparty democracy," they are even capable of launching coups against leaders who disagree with them-all in the name of protecting national sovereignty, which also presents an easy avenue for winning support from both the public and members of the Party. So in the face of such a threat, China's current leaders-for whom power is everything-always tend toward the official leftist stance in order to avoid attack from their political opponents and the public, never adopting new ideas that might threaten their status. Even if they know with full certainty that maintaining the status quo will guarantee a bigger crisis in the future, they will simply postpone the crisis for as long as possible. With the shift from lifetime appointments to rotating positions of power, China's political system seems headed in a progressive direction. But in fact it has also caused more damage: those in power strive to ensure that everything is satisfactory during their term, preferring to defer trouble to future terms instead. When the crisis breaks out, it will then appear unconnected to earlier leaders.

In my view, when the international community urges Chinese leaders to meet with the Dalai Lama; when the Dalai Lama wishes to communicate directly with Chinese leaders without using intermediaries; and when members of the Tibetan elite write letters of petition to the top leaders of the CCP, they do not really understand the determining factors within this situation. How to resolve the issue of Tibet is not something that the leaders of the CCP have the power to decide on their own. Certainly on some specific occasions, CCP leaders are able to deal with this issue in particular ways-but only in strategic ways that don't affect the substance of the issue. The tremendous influence and pervasiveness of anti-separatism forces within China's power structure should clearly indicate to us that CCP leaders, no matter how open-minded, are unable to resolve the Tibet question. In fact, that is little more than an impractical dream. •

\section{- Translated by Lingxi Kong and Tianle Chang - This text is an extract from Wang Lixiong, The Struggle for Tibet, London, Verso, 2009.}

